\title{
PENGARUH MOTIVASI, MINAT KEMANDIRIAN BELAJAR TERHADAP HASIL BELAJAR TARUNA POLITEKNIK ILMU PELAYARAN MAKASSAR (STUDI KASUS PELAKSANAAN UTS DAN UAS)
}

\author{
Arlizar Djamaan, M.Mar., Aslang, Muh. Jafar, Subehana Rachman, \\ Gradina Nur Fauziah \\ Politeknik IImu Pelayaran (PIP) Makassar \\ Jl. Tentara Pelajar No.173 - Makassar, Telp. 0411-316975
}

\begin{abstract}
ABSTRAK
Tujuan penelitian ini untuk mengetahui pengaruh motivasi dan kemandirian belajar terhadap hasil belajar taruna politeknik ilmu pelayaran Makassar. Subjek pada penelitian ini berjumlah 253 taruna. Data penelitian diperoleh dengan menggunakan angket motivasi dan angket kemandirian sertan menggunakan hasil belajar untuk porestasi belajar. Data penelitian yang diperoleh dianalisis dengan regresi sederhana untukm mengetahui pengaruh motivasi dan kemandirian terhadap prestasi belajar. Data dianalisis dengan bantuan program SPSS 22.0 for Windows. Hasil analisis hipotesis pertama menunjukkan bahwa terdapat pengaruh motivasi dengan prestasi belajar dengan nilai p signifikansi yang diperoleh $=0,000$. Dan hipotesis kedua menunjukkan bahwa terdapat pengaruh kemandirian dengan prestasi belajar dengan nilai $p$ signifikansi yang diperoleh $=0,000$
\end{abstract}

Kata kunci: Kemandirian; motivasi; prestasi belajar, taruna

\section{Pendahuluan}

Perguruan tinggi merupakan pusat penyelenggaraan dan pengembangan ilmu pengetahuan, teknologi dan atau kesenian sebagai suatu masyarakat ilmiah yang penuh cita-cita luhur guna mencerdaskan kehidupan bangsa dalam rangka mencapai tujuan nasional sebagaimana tercamtum dalam pembukaan Undang Undang Dasar 1945.

Politeknik IImu Pelayaran Makassar adalah salah satu Perguruan Tinggi atau sebuah lembaga Unit Pelaksana Teknis (UPT) dibawah 
Kementrian Perhubungan yang menyelenggarakan pendidikan profesional dibidang kemaritiman, dimana Polieknik IImu Pelayaran (PIP) Makassar dalam melaksanakan fungsinya sebagai Lembaga Pendidikan dan Latihan, mendidik para taruna/i program D - IV pelayaran dimasing masing bidang keahlian dimana terdapat tiga (3) bidang keahlian yakni : Nautika, Teknika dan Ketatalaksanaan Angkutan Laut dan Kepelabuhanan, sesuai dengan Keputusan Menteri Perhubungan No 96 tahun 2014 tentang Organisasi dan Tata Kerja Politeknik IImu pelayaran Makassar dan Keputusan Menteri Perhubungan No KM 18 tahun 1997 tentang Pendidikan Ujian Negara dan Sertifikasi Kepelautan. Politeknik IImu Pelayaran Makassar sebagai lembaga pendidikan dan latihan teknis kepelautan menyelenggarakan pendidikan profesional menekankan penerapan keahlian dibidang pelayaran, dan pembentukan kompetensi untuk menangani pekerjaan menurut praktek yang berlaku secara umum di bidang pelayaran. Selain itu Politeknik IImu Pelayaran (PIP) Makassar juga merupakan salah satu lembaga pendididikan Boarding School, dimana seluruh peserta didik dari tingkat satu (I) sampai dengan tingkat empat (IV) semester empat (IV) berada diasrama dalam menempuh pendidikan.

Dari tatap muka di kelas dan di Laboratorium serta workshoop selama Enam Belas (16) kali, akan memberikan sebuah gambaran bahwa proses pembelajaran sudah terlaksana dengan baik dengan asumsi bahwa taruna taruni sudah meyerap ilmu dengan pemahaman berdasarkan tujuan dari masing masing bidang keilmuannya. Proses pembelajaran yang dilaksanakan di Politeknik IImu Pelayaran (PIP) Makassar mengacu kepada kurikulum yang memenuhi persyaratan STCW 1978 Amandemen 2010 Manila, dimana kurikulum ini diorientasikan untuk mencapai keseimbangan afektif, kognitif, dan psikomotorik untuk Competency kepelautan. Ketiga aspek tersebut harus dapat dipadukan dan diseimbangkan mengingat tuntutan pekerjaan yang Profesionalisme disektor perhubungan laut yang sarat 
dengan resiko tinggi. Sebagai taruna, taruni, belajar adalah sebuah kewajiban yang harus dilakukan, terlepas dari semua kegiatan yang harus dilaksanakan sesuai dengan aturan yang mengikat mereka.

\section{Tinjauan Pustaka}

\subsection{Motivasi Belajar}

\section{Pengertian Motivasi Belajar}

Motivasi merupakan kondisi psikologis yang mendorong seseorang untuk melakukan sesuatu. Apabila kondisi psikologis seseorang baik maka dengan sendirinya motivasi untuk melakukan sesuatu juga akan baik. Dalam hal pembelajaran tentu perlu menjadi perhatian oleh pendidik karena tidak semua peserta datang ke kampus dengan kondisi psikologis yang sama karena ada pengaruh internal dan eksternal peserta didik itu sendiri. Untuk itu dalam perencanaan pembelajaran seorang pendidik perlu merancang sebuah strategi pembelajaran yang mampu memotivasi belajar peserta didik.

Definisi Motivasi belajar menurut Abdorrahman Gintings adalah "Sesuatu yang menggerakkan atau mendorong peserta didik untuk belajar atau menguasai materi pelajaran yang sedang diikutinya."

Dimyati dan Mudjiono mengemukakan definisi motivasi belajar sebagai "kekuatan mental yang mendorong terjadinya belajar atau dorongan mental yang menggerakkan dan mengarahkan perilaku manusia (perilaku belajar).Jadi motivasi belajar merupakan motivasi (dorongan) internal dan eksternal seorang peserta didik untuk belajar guna memperoleh prestasi yang baik. motivasi merupakan bagian dari learning. Dalam kegiatan pembelajaran pemberian motivasi sangat penting untuk diperhatikan, karena tidak semua pengajaran di kampus dapat menarik minat taruna/i. Motivasi dan belajar merupakan dua hal yang saling mempengaruhi. Motivasi belajar dapat timbul 
karena faktor intrinsik, berupa hasrat dan keinginan berhasil dan dorongan kebutuhan belajar, harapan akan cita-cita. Sedangkan faktor ekstrinsiknya adalah adanya penghargaan, lingkungan belajar yang kondusif, dan kegiatan belajar yang menarik.

Dalyono memaparkan dalam buku psikologi pendidikan bahwa "motivasi adalah daya penggerak/pendorong untuk melakukan sesuatu pekerjaan, yang bisa berasal dari dalam diri dan juga dari luar" (Dalyono, 2005: 55). Ngalim Purwanto, Sartain mengatakan bahwa motivasi adalah suatu pernyataan yang kompleks di dalam suatu organisme yang mengarahkan tingkah laku terhadap suatu tujuan (goal) atau perangsang (incentive). Tujuan adalah yang membatasi/menentukan tingkah laku organisme itu (Ngalim Purwanto, 2007 : 61).

Belajar adalah suatu proses yamg ditandai dengan adanya perubahan pada diri seseorang. Perubahan dalam diri seseorang dapat ditunjukkan dalam berbagai bentuk seperti berubahnya pengetahuannya, pemahamannya, sikap dan tingkah lakunya, keterampilan dan kemampuannya, daya reaksinya, daya penerimaannya dan lain-lain aspek yang ada pada individu (Sudjana,2002 :280). Sedangkan Djamarah mengemukakan bahwa belajar adalah "suatu aktifitas yang dilakukan secara sadar untuk mendapatkan sejumlah kesan dari bahan yang telah dipelajari" (Djamarah,1991:19-21). Motivasi belajar merupakan sesuatu keadaan yang terdapat pada diri seseorang individu dimana ada suatu dorongan untuk melakukan sesuatu guna mencapai tujuan.

Dari pendapat para tokoh diatas maka dapat ditarik kesimpulan bahwa motivasi merupakan kondisi fisiologis dan psikologis yang terdapat dalam diri seseorang yang mendorongnya untuk melakukan aktivitas tertentu guna mencapai suatu tujuan tertentu, termasuk didalamnya adalah kegiatan belajar. 


\section{a. Jenis - jenis motivasi belajar}

Berbicara tentang jenis dan macam motivasi dapat dilihat dari berbagai sudut pandang. Sardiman mengatakan bahwa motivasi itu sangat bervariasi yaitu :

(1) Motivasi dilihat dari dasar pembentukannya

a) Motif-motif bawaan adalah motif yang dibawa sejak lahir

b) Motif-motif yang dipelajari artinya motif yang timbul karena dipelajari.

(2) Motivasi menurut pembagiaan dari Woodworth dan Marquis dalam Sardiman:

a) Motif atau kebutuhan organis misalnya, kebutuhan minum, makan, bernafas, seksual, dan lain-lain.

b) Motif-motif darurat misalnya, menyelamatkan diri, dorongan untuk membalas, dan sebagainya.

c) Motif-motif objektif

3) Motivasi jasmani dan rohani

a) Motivasi jasmani, seperti, rileks, insting otomatis, napas dan sebagainya.

b) Motivasi rohani, seperti kemauan atau minat.

4) Motivasi intrisik dan ekstrinsik

a) Motivasi instrisik adalah motif-motif yang terjadi aktif atau berfungsi tidak perlu diransang dari luar, karena dalam diri setiap individu sudah ada dorongan untuk melakukan sesuatu.

b) Motivasi ekstrinsik adalah motif-motif yang aktif dan berfungsi karena adanya peransang dari luar.

Pendapat lain mengemukakan bahwa dua jenis motivasi yaitu motivasi primer yang merupakan motivasi yang didasarkan atas motif-motif dasar dan motivasi skunder yaitu motivasi yang dipelajari” (Dimyanti dan Mudjiono, 1999:88). 
Adapun bentuk motivasi yang sering dilakukan di lingkungan pendidikan adalah memberi angka, hadiah, pujian, gerakan tubuh, memberi tugas, memberi ulangan, mengetahui hasil, dan hukuman (Djmarah dan zain, 2002: 168).

Motivasi intrinsik adalah motif-motif yang menjadi aktif atau berfungsinya tidak perlu dirangsang dari luar, karena dalam diri setiap individu sudah ada dorongan untuk melakukan sesuatu. Misalnya saja seseorang yang senang membaca, tidak perlu ada yang mendorong atau menyuruhnya pun ia rajin mencari buku-buku untuk dibacanya. Kemudian jika dilihat dari segi tujuan kegiatan belajar yang dilakukannya, maka yang dimaksud dengan motivasi instrinsik disini adalah ingin mencapai tujuan yang terkandung didalam perbuatan belajar itu sendiri. Misalnya saja seorang taruna/i belajar karena dia memang benar-benar ingin mendapatkan pengetahuan/nilai atau ketrampilan tertentu dan tidak karena tujuan selain itu. Itulah sebabnya motivasi instrinsik juga dapat dikatakan sebagai bentuk motivasi yang didalamnya aktivitas belajar dimulai dan diteruskan berdasarkan suatu dorongan dari dalam diri dan secara mutlak berkaitan dengan aktivitas belajarnya.

Perlu diketahui bahwa taruna/i yang memiliki motivasi instrinsik akan memiliki tujuan menjadi orang yang terdidik, yang berpengetahuan, yang ahli dalam bidang studi tertentu. Satusatunya jalan untuk menuju ketujuan yang ingin dicapai adalah belajar, tanpa belajar tidak mungkin mendapat pengetahuan, dan tidak mungkin menjadi ahli. Dorongan yang menggerakkan itu bersumber pada suatu kebutuhan, kebutuhan untuk menjadi orang yang terdidik dan berpengetahuan. Jadi memang motivasi itu muncul dari kesadaran diri sendiri dengan tujuan secara esensial dan bukan hanya sekedar simbol. Dalam proses belajar, motivasi intrinsik memiliki pengaruh yang lebih efektif, 
karena motivasi intrinsik relatif lebih lama dan tidak tergantung pada motivasi dari luar (ekstrinsik).

Motivasi ekstrinsik adalah motif-motif yang aktif dan berfungsinya karena adanya perangsang dari luar. Seperti pujian, peraturan, tata tertib, teladan dosen, orangtua dan lain sebagainya. Sebagai contoh seseoarang itu belajar, karena tahu bahwa besok paginya akan ujian dengan harapan mendapat nilai baik sehingga akan dipuji oleh pacarnya atau temannya. Jadi dia belajar bukan karena ingin mengetahui sesuatu namun karena ingin mendapatkan nilai yang baik, atau agar mendapat hadiah.Oleh karena itu, motivasi ekstrinsik dikatakan sebagai bentuk motivasi yang didalam aktivitas belajarnya dimulai dan diteruskan berdasarkan dorongan dari luar.

Oleh karena itu perlu diketahui bahwa cara dan jenis menumbuhkan motivasi ada bermacam-macam. Akan tetapi untuk motivasi ekstrinsik kadang-kadang tepat, dan kadangkadang juga bisa kurang sesuai. Maka untuk itu seorang dosen harus hati-hati dalam menumbuhkan dan memberikan motivasi dalam kegiatan belajar anak didiknya sebab mungkin maksudnya memberi motivasi tetapi justru menjadikan tidak memberi keuntungan pada perkembangan belajar anak didiknya.

b. Ciri-Ciri Motivasi

Ciri-ciri motivasi menurut Sardiman adalah sebagai berikut :

1) Tekun menghadapi tugas (dapat bekerja terus menerus dalam waktu yang lama tidak pernah berhenti sebelum selesai)

2) Ulet menghadapi kesulitan (Tidak lekas putus asa). Tidak memerlukan dorongan dari luar untuk berprestasi setinggi mungkin (tidak cepat puas dengan prestasi yang dicapainya) 
3) Menunjukkan minat terhadap bermacam-macam masalah

4) Lebih senang bekerja mandiri

5) Cepat bosan pada tugas-tugas yang rutin (hal-hal yang bersifat mekanis, berulang-ulang begitu saja, sehingga kurang kreatif)

6) Dapat mempertahankan pendapatnya (kalau sudah yakin akan sesuatu)

7) Tidak mudah melepaskan hal yang diyakini itu.

8) Senang mencari dan memecahkan masalah soal-soal.

Jadi apabila seseorang memiliki ciri-ciri seperti diatas berarti orang itu selalu memiliki motivasi yang cukup kuat. Dan dalam kegiatan belajar mengajar akan berhasil baik, kalau taruna/i memiliki ciri-ciri seperti diatas.

\section{c. Strategi Menumbuhkan Motivasi Belajar Peserta Didik}

Dalam kegiatan belajar, motivasi peserta didik adalah salah satu tolak ukur menetukan keberhasilan dalam pembelajaran. Peserta didik yang tidak mempunyai motivasi belajar tidak akan mungkin melakukan aktivitas belajar. Tidak adanya aktivitas belajar tentu akan berdampak terhadap tujuan pembelajaran. Apabila tujuan pembelajaran tidak tercapai, mencerminkan kegagalan yang dilakukan pendidik. Untuk itu, pendidik perlu menciptakan strategi yang tepat dalam memotivasi belajar peserta didik.

Menurut Pupuh Fathurrohman dan M. Sorby Sutikno (2010) bahwa motivasi dapat dibagi dua. Pertama motivasi intrinsik, yaitu motivasi yang timbul dari dalam diri peserta didik tanpa ada paksaan dari dorongan orang lain. Kedua motivasi ekstrinsik, yaitu motivasi yang timbul sebagai akibat pengaruh dari luar peserta didik. Hal ini bisa timbul karena ajakan, suruhan, atau paksaan dari orang lain (pendidik) sehingga 
dengan keadaan tersebut peserta didik mau melakukan sesuatu atau belajar.

Pendapat tersebut menegaskan bahwa dalam pembelajaran motivasi ektrinsik sangat dibutuhkan oleh peserta didik, seperti hadiah (reward), kompetensi sehat antarpeserta didik, pemberian nasehat, dan pemberian hukuman (funishment). Adanya motivasi dari luar sebagaidorungan untuk diri peserta didik merupakan sebuah kemutlakan harus dilkukan guru jika menginginkan peserta didiknya mencapai keberhasilan dalam pembelajaran. Lain halnya dengan peserta didik yang memiliki motivasi intrinsik karena mereka dengan kesadaran sendiri ingin belajar dan memperhatikan penjelasan guru dalam pembelajaran, karena keingintahuannya dalam pembelajaran tinggi sehingga sulit terpengaruh oleh gangguan yang ada di sekitarnya.

Oemar Hamalik (2002) secara umum menyebutkan tiga fungsi motivasi, yaitu:

1. Mendorong manusia untuk berbuat (sebagai penggerak) yang merupakan langkah penggerak dari setiap kegiatan.

2. Menentukan arah perbuatan, yakni kearah tujuan yang hendak dicapai sehingga dapat memberikan arah dan kegiatan yang harus dikerjakan sesuai dengan rumusan tujuannya.

3. Menyeleksi perbuatan, yakni menetukan perbuatanperbuatan yang harus dikerjakan yang serasi guna mencapai tujuan, dengan menyisihkan perbuatan-perbuatan yang tidak bermanfaat bagi tujuan tersebut.

Berdasarkan pendapat tersebut dapat diketahui bahwa motivasi berfungsi sebagai pendorong, pengarah, dan sekaligus sebagai penggerak prilaku seseorang untuk mencapai suatu tujuan. Begitu juga halnya dalam pencapaian tujuan 
pembelajaran, guru merupakan faktor yang penting untuk mengusahakan terlaksananya fungsi-fungsi tersebut dengan cara dan strategi yang tepat untuk menumbuhkan motivasi belajar peserta didik.

Strategi menumbuhkan motivasi belajar peserta didik sangat ditentukan oleh perencanaan yang dibuat guru dalam pembelajaran. Dengan strategi motivasi yang tepat akan mampu memberikan kesuksesan dalam pembelajaran. Sebagaimana yang dikemukakan Wina Sanjaya (2006), bahwa strategi digunakan untuk memperoleh kesuksesan atau keberhasilan dalam mencapai tujuan.

\subsection{Kerangka Pikir}

Dalam meningkatkan mutu pendidikan berbagai upaya telah dilakukan diantara upaya itu adalah memberikan Motivasi dengan segala cara dan metode agar para taruna/i mampu mengembangkan potensi yang dimilikinya sehingga dengan demikian minat untuk belajar kelompok maupun mandiri semakin tumbuh dalam diri mereka. Beberapa kegiatan diluar dari perkuliahan yang terjadwalpun semakin menambah khasana untuk membangun motivasi dan minat para taruna/i dalam konteks kemandirian belajar.

Melalui beberapa kegiatan dan metode dalam memberikan perkuliahan diharapkan taruna/i mampu memotivasi dan minat mereka sehingga taruna/i dalam menghadapi ujian tengah semester dan ujian akhir semester tidak lagi tergantung kepada contekan atau kepada teman yang lain. Kemandirian belajar adalah salah satu faktor yang menjadi terbangunnya kepercayaan diri disetiap taruna/i dalam menghadapi UTS dan UAS. Dengan demikian Motivasi dan Minat kemandirian belajar sebagai jalan 
yang sangat menunjang Peningkatan hasil belajar taruna/i Politeknik IImu Pelayaran (PIP) Makassar.

Adapun Kerangka Pikir digambarkan dalam bentuk Skema sebagai berikut :

\section{Motivasi Belajar \\ a. Faktor Instristrik (Keinginan berhasil, dorongan kebutuhan, harapan akan cita-cita) \\ b. Faktor Ekstrinstik (Penghargaan, lingkungan belajar yang kondusif, kegiatan belajar yang menarik)}

\section{Kemandirian Belajar}

a. Mempunyai inisiatif

b. Bertanggung jawab

c. Percaya diri

\section{Metode Penelitian}

Pada penelitian ini, metode penelitian yang digunakan adalah metode survey untuk melihat secara langsung ke lapangan tentang variable atau indikator-indikator mana yang paling berpengaruh dalam Motivasi dan Kemandirin Belajar Taruna/l Politeknik IImu Pelayaran Makassar.

Kecenderungan untuk menggunakan metode penelitian survey ini didasarkan pada pertimbangan bahwa metode ini dianggap sangat relevan dengan materi penulisan ini yakni untuk mendapatkan data yang objektif dan valid dalam rangka memahami tentang Motivasi dan Kemandirin Belajar Taruna/l Politeknik IImu Pelayaran Makassar 


\section{Hasil dan Pembahasan}

\section{1. Data hasil belajar}

Data hasil belajar memiliki interval nilai 0-100 Rentang skor minimum 0 dan maksimumnya adalah 100 . maka standar deviasinya adalah 100/6 $=16,67$ dan Mean hipotetik $=50$. Hasil penelitian menunjukkan bahwa skor maksimum yang diperoleh subjek sebesar 75 dan skor minimum sebesar 60 . Dengan Mean empirik sebesar 64,90, standar deviasi sebesar 3,68. Data tersebut menunjukkan bahwa mean empirik lebih besar dibandingkan dengan mean hipotetik. Hal ini berarti tingginya keadaan subjek pada variabel yang diteliti, atau dengan kata lain dikatakan hasil belajar taruna termasuk dalam kategori tinggi.

Adapun kategorisasi prestasi belajar yang dimiliki oleh taruna adalah sebagai berikut:

Tabel 2 Norma kategorisasi skor variabel prestasi belajar

\begin{tabular}{|c|c|c|c|}
\hline Interval skor & Frekuensi & Persentasi (\%) & $\begin{array}{c}\text { Kategor } \\
\mathbf{i}\end{array}$ \\
\hline $\mathrm{X}<21$ & 0 & 0 & Rendah \\
\hline $21 \leq \mathrm{X}<77$ & 253 & 100 & Sedang \\
\hline $77 \leq \mathrm{X}$ & 0 & 0 & Tinggi \\
\hline Total & $\mathbf{2 5 3}$ & $\mathbf{1 0 0}$ & \\
\hline
\end{tabular}

Hasil Kategorisasi tersebut menunjukkan bahwa taruna memiliki prestasi belajar dalam kategori yang sedang.

\subsection{Data motivasi}

Skala motivasi memiliki item sebanyak 16 butir, dengan rentang skor dari 1 sampai 5 . Rentang skor minimum dan maksimumnya adalah $16 \times 1=16$ sampai dengan $16 \times 5=80$. Sehingga luas sebarannya adalah $80-16=64$, maka standar 
deviasinya adalah $64 / 6=10,67$ dan Mean hipotetik sebesar $16 \times 3$ (nilai tengah) $=48$. Hasil penelitian menunjukkan bahwa skor maksimum yang diperoleh subjek sebesar 46 dan skor minimum sebesar 23. Dengan Mean empirik sebesar 48, standar deviasi sebesar 10,67. Data tersebut menunjukkan bahwa mean empirik lebih besar dibandingkan dengan mean hipotetik. Hal ini berarti tingginya keadaan subjek pada variabel yang diteliti, atau dengan kata lain dikatakan bahwa motivasi taruna termasuk dalam kategori tinggi.

Adapun kategorisasi motivasi yang dimiliki oleh taruna adalah sebagai berikut:

Tabel 3 Norma kategorisasi skor variabel Motivasi

\begin{tabular}{|c|c|c|c|}
\hline Interval skor & Frekuensi & Persentasi (\%) & Kategori \\
\hline $\mathrm{X}<31$ & 30 & 12 & Rendah \\
\hline $31 \leq \mathrm{X}<65$ & 223 & 88 & Sedang \\
\hline $65 \leq \mathrm{X}$ & 0 & 0 & Tinggi \\
\hline Total & $\mathbf{2 5 3}$ & $\mathbf{1 0 0}$ & \\
\hline
\end{tabular}

Hasil Kategorisasi tersebut menunjukkan bahwa taruna memiliki motiovasi dalam kategori yang sedang.

\subsection{Data Kemandirian}

Skala kemandirian memiliki item sebanyak 6 butir, dengan rentang skor dari 1 sampai 5 . Rentang skor minimum dan maksimumnya adalah $6 \times 1=6$ sampai dengan $6 \times 5=30$. Sehingga luas sebarannya adalah $30-6=24$, maka standar deviasinya adalah 24/6 $=4$ dan Mean hipotetik sebesar $6 \times 3$ (nilai tengah $)=18$. Hasil penelitian menunjukkan bahwa skor maksimum yang diperoleh subjek sebesar 26 dan skor minimum sebesar 6. Dengan Mean empirik sebesar 18,58, standar deviasi sebesar 4,40. Data tersebut menunjukkan bahwa mean empirik lebih besar dibandingkan dengan mean 
hipotetik. Hal ini berarti tingginya keadaan subjek pada variabel yang diteliti, atau dengan kata lain dikatakan bahwa kemandirian taruna termasuk dalam kategori tinggi.

Adapun kategorisasi kemandirian yang dimiliki oleh taruna adalah sebagai berikut:

Tabel 4. Norma kategorisasi skor variabel kemandirian

\begin{tabular}{|c|c|c|c|}
\hline $\begin{array}{c}\text { Interval } \\
\text { skor }\end{array}$ & Frekuensi & Persentasi (\%) & Kategori \\
\hline $\mathrm{X}<31$ & 30 & 18 & Rendah \\
\hline $31 \leq \mathrm{X}<65$ & 223 & 82 & Sedang \\
\hline $65 \leq \mathrm{X}$ & 0 & 0 & Tinggi \\
\hline Total & $\mathbf{2 5 3}$ & $\mathbf{1 0 0}$ & \\
\hline
\end{tabular}

Hasil Kategorisasi tersebut menunjukkan bahwa taruna memiliki kemandirian dalam kategori yang sedang.

\subsection{Pembahasan}

Hasil penelitian menunjukkan bahwa motivasi dapat meningkatkan prestasi belajar taruna. Hal ini mendukung teori Makmun (2003) bahwa esensi motivasi yaitu pertama, motivasi merupakan suatu kekuatan (power) atau daya (energy), kedua motivasi merupakan keadaan yang kompleks (a complex state) dan kesiap sediaan (preparatory set) dalam diri individu untuk bergerak (to move, motion, motive) ke arah tujuan tertentu, baik disadari maupun tidak disadari (Makmun, 2003). Selanjutnya Winkel, (2004) bahwa motivasi adalah keseluruhan daya penggerak psikis di dalam diri siswa yang dapat menimbulkan, menjamin kelangsungan dan memberikan arah pada aktivitas belajar untuk mencapai suatu tujuan. Motivasi merupakan bagian dari learning. Motivasi sangat penting dalam proses belajar-mengajar sebagaimana pendapat Mc Connel yang menyatakan bahwa tidak ada suatu masalah dalam mengajar yang lebih penting daripada 
motivasi. Motivasi belajar sangat dibutuhkan peserta didik sebagai pembelajar untuk keberhasilan proses pembelajaran (Sahabuddin, 2007:142). Peserta didik yang tidak memiliki motivasi, tidak akan berusaha keras untuk belajar.

Motivasi terjadi sebagai hasil kebutuhan mendasar yang diperoleh ketika individu mengorganisasikan objek atau peristiwa yang telah direncanakan (Alberto \& Troutman, 1995:19). Kebutuhan jasmaniah, sosial, dan intelektual merupakan kebutuhan peserta didik yang diperlukan dalam proses belajar-mengajar. Kebutuhan jasmani bersifat jasmaniah seperti makan, minum, tidur, pakaian, dsb. Kebutuhan sosial berupa keinginan bergaul dengan teman, guru, dan masyarakat. Kebutuhan intelektual terkait dengan minat siswa mempelajari sesuatu ilmu pengetahuan (Sardiman, 2008).

Manusia berperilaku atas dasar tujuan, terarah pada tujuan yang dianggap dapat memenuhi kebutuhan individu. Motivasi bekerja menurut tiga fungsi, yaitu fungsi memberikan kekuatan, fungsi menyaring, fungsi mengarahkan. Dalam kegiatan belajar, motivasi peserta didik adalah salah satu tolak ukur menetukan keberhasilan dalam pembelajaran. Peserta didik yang tidak mempunyai motivasi belajar tidak akan mungkin melakukan aktivitas belajar. Tidak adanya aktivitas belajar tentu akan berdampak terhadap tujuan pembelajaran. Apabila tujuan pembelajaran tidak tercapai, mencerminkan kegagalan yang dilakukan pendidik. Untuk itu, pendidik perlu menciptakan strategi yang tepat dalam memotivasi belajar peserta didik.

Motivasi belajar yang dimiliki peserta didik berfungsi sebagai alat pendorong terjadinya prilaku belajar peserta didik, alat untuk mempengaruhi prestasi belajar peserta didik, 
alat untuk memberikan direksi terhadap pencapaian tujuan pembelajaran, dan alat untuk membangun sistem pembelajaran yang bermakna. Oemar Hamalik (2002) secara umum menyebutkan tiga fungsi motivasi, yaitu:

Mendorong manusia untuk berbuat (sebagai penggerak) yang merupakan langkah penggerak dari setiap kegiatan.; menentukan arah perbuatan, yakni kearah tujuan yang hendak dicapai sehingga dapat memberikan arah dan kegiatan yang harus dikerjakan sesuai dengan rumusan tujuannya.; menyeleksi perbuatan, yakni menetukan perbuatan-perbuatan yang harus dikerjakan yang serasi guna mencapai tujuan, dengan menyisihkan perbuatan-perbuatan yang tidak bermanfaat bagi tujuan tersebut. Begitu juga halnya dalam pencapaian tujuan pembelajaran, guru merupakan faktor yang penting untuk mengusahakan terlaksananya fungsi-fungsi tersebut dengan cara dan strategi yang tepat untuk menumbuhkan motivasi belajar peserta didik.

\section{Penutup}

\subsection{Kesimpulan}

a. Motivasi dapat berpengaruh terhadap hasil belajar taruna. Semakin tinggi Motivasi yang dimliki oleh taruna semakin tinggi pula hasil prestasi belajar taruna.

b. Kemandirian dapat berpengaruh terhadap hasil belajar taruna. Semakin tinggi kemandirian yang dimliki oleh taruna semakin tinggi pula hasil prestasi belajar taruna. 


\subsection{Saran}

Subjek Penelitian, diharapkan dapat meningkatkan motivasi belajar dan kemandirian dengan mengikuti kegiatan-kegiatan yang dapat meningkatkan motivasi dan kemandirian diantaranya mengikuti pelatihan soft skill dan yang lainnya.

a. Pihak Kampus dapat menfasilitasi para taruna dengan cara menyelenggarakan kegiatan-kegiatan pelatihan.

\section{Daftar Pustaka}

Abdorrahman Gintings, (2001), Dasar-dasar motivasi dalam lingkungan kerja, Jakarta : Ghalia Indonesia

Abizer, 1998. Komunikasi organisasi Jakarta : PPCPTK diikuti Depdikbud

Azwar, S. 2010. Penyusunan skala psikologi. Yogyakarta: Pustaka Pelajar

Danim sudarmawan, 2010. Profesionalisasi dan Etika Profesi Guru. Bandung : Alpabeta

Dimyati dan Mudjiono. 2007. Manajemen Kelas untuk Menciptakan Iklim Belajar yang Kondusif. Jakarta : Visindo

Djamarah, Saiful Bakri. 2002. Strategi belajar mengajar Jakarta: Rieke Cipta

Drs. M. Dalyono. 2003. Manajemen Motivasi. Jakarta : Grasindo

Gerungan, W.A....., Psicology Sosial Bandung Gresco 1996 Harey, Paul dan Kenneth H. Blancheard. Management of organizational Behavier, Utilizing Human Resources fith Edition, Englewood Clhift New Jespy Printice hill. 1988.

Hadi, S. 1992. Statistik 2. Yogyakarta: Fakultas Psikologi Univesitas Gadjah Mada, Hamalik, Oemar.1995. Kurikulum dan Pembelajaran, Jakarta : Bumi Aksara,

Harsey, Paul \& Kenneth $H$. Blanchard. Managament of Organizational Behavior, 